\title{
Pengaruh Kompetensi Dan Motivasi Kerja Guru Terhadap Hasil Belajar Siswa Madrasah Tsanawiyah
}

\author{
Anis Fauzi ${ }^{* 1)}$; Duriyat ${ }^{2}$ \\ ${ }^{1}$ Universitas Islam Negeri Sultan Maulana Hasanuddin Banten, Indonesia \\ ${ }^{2}$ Kementerian Agama Kabupaten Serang, Indonesia \\ Koresponden Author:Jantera_Anis@yahoo.com
}

\begin{abstract}
The aim of this research is to investigate the teachers' competence and work motivation, as well as the students' achievement. It is specific for Islam education teachers (PAI); PAI teachers' competence and work motivation, and to determine the students' learning outcomes at Madrasah Tsanawiyah according to KKM of MTs Negeri 1 Serang. The research instrument used are questionnaire, test and documentation. The collected data was analyzed by using quantitative data with descriptive statistics, and multiple regression analysis. After the researcher conducted the hypothesis testing, the following conclusions were obtained: First, the teachers' competence, teachers' work motivation, and the students' achievement are classified as medium category. Second, there is a significant influence of PAI teachers' competence towards the students' achievement at Madrasah Tsanawiyah based on KKM of MTs Negeri 1 Kabupatten Serang taking up to 5.3\%. Third, there is a significant influence of PAI teachers' work motivation towards students' achievement at Madrasah Tsanawiyah based on KKM of MTs Negeri 1 Serang as much as $15,5 \%$. Fourth, there is a significant influence of PAI teachers' competence and work motivation toward students' achievement at Madrasah Tsanawiyah based on KKM of MTs Negeri 1 Serang at 5.5\%. Finally, it can be concluded that the influence of PAI teachers' competence and work motivation toward students' achievement at Madrasah Tsanawiyah based on KKM of MTs Negeri 1 Serang is only 5.5\%.
\end{abstract}

Keywords: teacher competence; teacher motivation; student learning outcome

\begin{abstract}
Abstrak
Tujuan penulisan ini adalah untuk mengetahui gambaran kompetensi guru, motivasi kerja guru rumpun PAI, dan hasil belajar siswa Madrasah Tsanawiyah se-KKM MTs Negeri 1 kabupaten Serang. Metode pengumpulan data yang digunakan dalam penelitian ini adalah angket, test dan dokumentasi dengan analisis regresi berganda. Hasil penelitian menunjukan bahwa pertama, kompetensi guru, motivasi kerja guru, dan hasil belajar siswa di Madrasah Tsanawiyah se KKM MTs Negeri 1 Kabupaten Serang termasuk dalam kategori sedang; Kedua, ada pengaruh yang signifikan dari kompetensi guru rumpun PAI terhadap hasil belajar siswa Madrasah Tsanawiyah se KKM MTs Negeri 1 Kabupaten Serang sebesar 5,3\%; Ketiga, ada pengaruh yang signifikan dari motivasi kerja guru rumpun PAI terhadap hasil belajar siswa Madrasah Tsanawiyah se KKM MTs Negeri 1 Kabupaten Serang sebesar 15,5 \%; Keempat, ada pengaruh yang signifikan dari kompetensi dan motivasi kerja guru rumpun PAI terhadap hasil belajar siswa Madrasah Tsanawiyah se KKM MTs Negeri 1 kabupaten Serang sebesar 5,5 \%. Dengan demikian secara umum dapat disimpulkan bahwa pengaruh kompetensi dan motivasi kerja guru rumpun PAI terhadap hasil belajar siswa Madrasah Tsanawiyah se KKM MTs Negeri 1 Kabupaten Serang hanya sedikit saja yakni 5,5 persen.
\end{abstract}

\section{Kata kunci : kompetensi guru; motivasi kerja guru; hasil belajar}

\section{A. Pendahuluan}

Salah satu komponen penting dalam pendidikan adalah guru. Guru dalam konteks pendidikan mempunyai peranan yang besar dan strategis. Hal ini disebabkan gurulah yang berada dibarisan terdepan dalam pelaksanaan pendidikan. Gurulah yang langsung berhadapan 
dengan peserta didik untuk mentransfer ilmu pengetahuan dan teknologi sekaligus mendidik nilai-nilai positip melalui bimbingan dan keteladanan. ${ }^{1}$

Guru sebagai pemegang amanat harus bertanggung jawab atas segala amanat yang diserahkan kepadanya, hal ini dijelaskan dalam firman Allah Surat An Nisa ayat 58: "Sungguh Allah menyuruhmu menyampaikan amanat kepada yang berhak menerimanya, dan apabila kamu menetapkan hukum di antara manusia hendaknya kamu menetapkannya dengan adil. Sungguh Allah sebaik-baik yang memberi pengajaran kepadamu. Sungguh Allah Maha mendengar, Maha melihat. ${ }^{2}$

Guru sebagai salah satu komponen dalam kegiatan pembelajaran, memiliki posisi yang sangat menentukan keberhasilan pembelajaran, karena fungsi utama guru ialah merancang, mengelola, melaksanakan, dan mengevaluasi pembelajaran. Guru adalah pendidik profesional yang mempunyai tugas, fungsi dan peran penting dalam merencanakan kehidupan bangsa. Kedudukan guru dalam kegiatan pembelajaran juga sangat strategis dan menentukan. Salah satu faktor yang mempengaruhi keberhasilan tugas guru ialah kinerjanya dalam merencanakan, melaksanakan dan mengevaluasi proses belajar mengajar.

Pemerintah dan masyarakat memiliki harapan besar terhadap guru. Guru diharapkan menjadi seorang profesional dan memiliki kompetensi dalam melaksanakan kewajiban sebagai pendidik. Berdasarkan Undang Undang Republik Indonesia Nomor 14 tahun 2005 tentang Guru dan Dosen, disebutkan bahwa Guru adalah pendidik profesional dengan tugas utama mendidik, mengajar, membimbing, mengarahkan, melatih dan mengevaluasi peserta didik pada pendidikan anak usia dini jalur pendidikan formal, pendidikan dasar, dan pendidikan menengah. ${ }^{3}$

Guru merupakan penanggung jawab proses belajar mengajar yang berlangsung didalam kelas. Selain itu, guru memiliki peranan yang sangat penting dalam menentukan kualitas dan kuantitas pengajaran yang dilaksanakannya. Guru adalah salah satu komponen manusia dalam proses belajar mengajar, yang ikut berperan dalam usaha pembentukan sumber daya manusia yang potensial di bidang pembangunan. ${ }^{4}$

Guru merupakan elemen kunci dalam sistem pendidikan, khususnya di sekolah. Semua komponen lain, mulai dari kurikulum, sarana prasarana, biaya, dan sebagainya akan berarti apabila esensi pembelajaran yaitu interaksi guru dengan peserta didik berkualitas. Berdasarkan Undang Undang Republik Indonesia Tahun 2005 tentang Guru dan Dosen disebutkan bahwa seorang guru yang profesional dituntut dengan sejumlah persyaratan minimal, antara lain memiliki kualifikasi pendidikan yang memadai, memiliki kompetensi keilmuan sesuai dengan bidang yang ditekuninya, memiliki kemampuan berkomunikasi yang baik dengan anak didiknya, mempunyai jiwa kreatif dan produktif, mempunyai etos kerja dan komitmen tinggi terhadap profesinya, dan selalu melakukan pengembangan diri secara terus menerus (continous inprovement) melalui organisasi profesi, internet, buku, seminar dan semacamnya.

Karena itu Undang Undang ini memberikan persyaratan yang kompleks untuk menjadi guru mulai dari Taman Kanak-Kanak sampai dengan Sekolah Menengah, yaitu dikatakan bahwa guru wajib memiliki kualifikasi akademik, kompetensi, sertifikat pendidik, sehat jasmani dan rohani, serta memiliki kemampuan untuk mewujudkan tujuan pendidikan nasional. ${ }^{5}$ Kualifikasi dan kompetensi yang harus dimiliki guru selanjutnya dijelaskan dalam

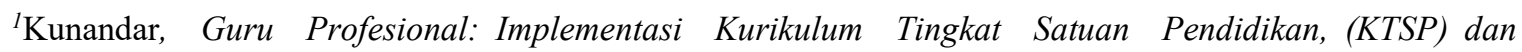
Persipan Menghadapi Sertifikasi Guru, (Jakarta: Raja Grafindo, 2007), h. 5.

${ }^{2}$ Kementerian Agama RI, Al Qur'an dan Terjemahannya, (PT Sinergi Pustaka Indonesia, 2012), h.113

${ }^{3}$ Undang-Undang Republik Indonesia Nomor 14 Tahun 2005 Tentang Guru dan Dosen.

${ }^{4}$ Sardiman, Interaksi dan Motivasi Belajar Mengajar, (Jakarta: Raja Grafindo Persada, 2004), h. 125.

${ }^{5}$ Ibid.
} 
pasal 8, pasal 9, dan pasal 10. Kualifikasi akademik sebagaimana dimaksud dalam pasal 8 diperoleh melalui pendidikan tinggi program sarjana atau program diploma empat. ${ }^{6}$

Oleh karena itu, guru merupakan salah satu unsur dibidang pendidikan yang harus berperan aktif dan menempatkan keududukannya sebagai tenaga profesional. Kompetensi merupakan salah satu kualifikasi guru yang terpenting. Bila kompetensi ini tidak ada pada diri seorang guru, maka ia tidak akan berkompeten dalam melakukan tugasnya dan hasilnya pun tidak akan optimal. Dalam Islam, Allah SWT mengistimewakan manusia dengan akal, kesanggupan membedakan serta kesanggupan menerima ilmu dan berbagai pengetahuan serta membuat gagasan-gagasan yang menjadikannya mampu menguasai alam wujud. ${ }^{7}$

Penguasaan empat kompetensi mutlak harus dimiliki setiap guru untuk menjadi tenaga pendidik yang profesional seperti yang disyaratkan Undang Undang Guru dan Dosen. Kompetensi guru dapat diartikan sebagai kebulatan pengetahuan, keterampilan dan sikap yang ditampilkan dalam bentuk perilaku cerdas dan penuh tanggung jawab yang dimiliki seorang guru dalam menjalankan profesinya. ${ }^{8}$

Profesi diartikan sebagai suatu jabatan atau pekerjaan tertentu yang mensyaratkan pengetahuan dan keterampilan khusus yang diperoleh dari pendidikan akademis yang intensif. Jadi, profesi adalah suatu pekerjaan atau jabatan yang menuntut keahlian tertentu. Artinya suatu pekerjaan atau jabatan yang disebut profesi tidak dapat dipegang oleh sembarang orang, tetapi memerlukan persiapan melalui pendidikan dan pelatihan secara khusus.

Sertifikat profesi guru diberikan pemerintah melalui lembaga pelaksana sertifikasi jika yang bersangkutan telah memenuhi persyaratan-persyaratan yang ditentukan sehingga layak disebut sebagai guru profesional. Profesionalitas guru untuk memperoleh guru profesional tersebut sedikitnya harus memiliki karakteristik sebagai berikut : (1) Memiliki landasan teologis dan filosofis yang mantap, (2) Memiliki landasan pengetahuan yang kuat, (3) Berdasarkan kompetensi individual bukan atas dasar KKN, (4) Memiliki sistem seleksi dan sertifikasi yang akurat, (5) Ada kerjasama dan kompetisi yang sehat antar teman sejawat dan antar lembaga, (6) Adanya kesadaran profesional yang tinggi, (7) Memiliki prinsip-prinsip etik yang berupa kode etik, (8) Memiliki sitem sanksi profesi yang jelas, (9) Adanya militansi individual, (10) Memiliki otganisasi profesi, dan (11) Memiliki jaminan mutu. ${ }^{9}$

Perwujudan guru profesional yang bermutu sebagaimana diuraikan diatas, menuntut berbagai perbaikan terhadap program sertifikasi yang berlangsung sekarang ini agar hasilnya dapat memberikan jaminan terhadap kinerja dan kemampuan guru dalam melakukan pekerjaan secara profesional. Tanpa sertifikasi yang tepat dengan berbagai karakteristik diatas, dapat menimbulkan berbagai permasalahan dalam sistem pembinaan dan pengembangan profesi guru. Perlunya perbaikan sistem dan manajemen sertifikasi guru juga sesuai dengan Undang Undang Sistim Pendidikan Nasional No. 20 tahun 2003 dan Standar Nasional Pendidikan. Dalam Undang Undang dan Peraturan tersebut telah dikemukakan bahwa sertifikasi guru harus meliputi kompetensi kemampuan bidang studi, pemahaman karakteristik peserta didik, pembelajaran yang mendidik, serta pengembangan profesi dan kepribadian pendidik. ${ }^{10}$

Proses belajar dan hasil belajar para siswa bukan saja ditentukan oleh sekolah, pola, struktur, dan isi kurikulumnya, akan tetapi sebagian besar ditentukan oleh kompetensi guru yang mengajar dan membimbing mereka. Guru yang kompeten akan lebih mampu

${ }^{6}$ Ibid, 7.

${ }^{7}$ M. Masyhur Amin, Pengantar Ke arah Metode Penelitian dan Pengembangan Ilmu Pengetahuan Agama Islam, (Yogyakarta: P3M 1AIN Sunan Kalijaga, 1992), h. 208.

${ }^{8}$ E. Mulyasa, Standar Kompetensi dan Sertifikasi Guru, Cet. 3, (Bandung: Remaja Rosdakarya, 2008), h. 25.

${ }^{9}$ M. Masyhur Amin, Pengantar Ke arah Metode, h. 32.

${ }^{10}$ Ibid, 37. 
menciptakan lingkungan belajar yang efektif, menyenangkan, dan akan lebih mampu mengelola kelasnya, sehingga kegiatan belajar para siswa berada pada tingkat optimal. ${ }^{11}$

Meskipun demikian, pelaksanaan sertifikasi guru ini tidak sedikit menuai badai dan hasil yang mengecewakan ketika para guru yang telah disertifikasi dan telah mendapatkan tunjangan profesi tidak menunjukkan kinerja yang berkualitas. Dengan kata lain, mutu guruguru yang telah disertifikasi tidak menunjukkan peningkatan yang signifikan, sehingga menimbulkan berbagai permasalahan di sekolah/lapangan, kecemburuan sosial, dan bahkan saling lempar pekerjaan apalagi jika guru yang sudah disertfikasi tersebut usianya lebih muda daripada guru lain yang belum tersertifikasi.

Gambaran kondisi guru saat ini dapat dilihat secara kuantitatif dan kualitatif. Secara kuantitatif jumlah guru di Indonesia, sesungguhnya tidak kekurangan. Yang terjadi adalah ketidakmerataan distribusi guru terutama di luar Jawa dan di daerah pedesaan. Secara kualitatif dapat dilihat dari berbagai indikator, diantaranya adalah tingkat pendidikan terakhir atau kualifikasi, kelayakan mengajar, serta kesejahteraan. Yang terakhir ini dapat menjadi salah satu indikator karena asumsinya kesejahteraan yang baik dapat mendorong guru meningkatkan kualitas atau profesionalitasnya. ${ }^{12}$

Selain problem ketidakmerataan distribusi dan rendahnya kualitas pendidikan guru, problem lain yang dihadapi pada masalah keguruan adalah banyak guru yang berprofesi ganda sebagai pejabat pemerintahan desa dan sebagai istri pejabat pemerintahan yang masih tercatat sebagai guru, namun tidak menjalankan fungsi sebagai pengajar. Banyak pula guru yang mengajar di luar bidang keahliannya. Kondisi yang buruk ini terutama banyak di jumpai di lembaga pendidikan madrasah swasta. Bahkan tidak sedikit dari guru madrasah di semua tingkatan (MI, MTs, dan MA) diketahui salah tempat dan berkualifikasi rendah. Mereka pada umumnya lulusan program studi Pendidikan agama Islam yang terpaksa mengajar mata pelajaran umum, seperti Bahasa Indonesia, Sejarah, IPA, bahkan Matematika. ${ }^{13}$

Salah satu upaya untuk menyediakan guru yang profesional dan berkualitas adalah guru tidak hanya memiliki kualifikasi akademik, namun juga harus memiliki kompetensi dan sertifikasi yang memenuhi persyaratan. Namun sayangnya dalam kultur masyarakat Indonesia saat ini pekerjaan guru masih cukup tertutup. Bahkan atasan guru seperti Kepala Madrasah dan Pengawas sekalipun tidak mudah untuk mendapatkan data dan mengamati realita keseharian performance guru dihadapan peserta didik. Program kunjungan kelas oleh Kepala Madrasah atau Pengawas tidak bisa ditolak oleh guru. Akan tetapi guru berusaha menampakkan kinerja terbaiknya, baik pada aspek perencanaan maupun pelaksanaan hanya pada saat dikunjungi. Selanjutnya ia akan kembali bekerja seperti sedia kala, kadang tanpa persiapan yang matang serta tanpa semangat, antusiasme dan kreativitas yang tinggi. ${ }^{14}$

Selain hal-hal tersebut diatas, hal lain yang sangat penting dimiliki oleh guru adalah motivasi. Malone membedakan bentuk motivasi yang meliputi motivasi instrinsik dan motivasi ekstrinsik. ${ }^{15}$ Teori diatas, diperjelas oleh Hamzah B. Uno yang mengatakan bahwa motivasi kerja adalah dorongan dari dalam diri dan luar diri seseorang untuk melakukan sesuatu yang terlihat dari dimensi internal dan dimensi eksternal. ${ }^{16}$

Belajar dan hasil belajar para siswa bukan saja ditentukan oleh sekolah, pola, struktur dan isi kurikulumnya, akan tetapi sebagian besar ditentukan oleh kompetensi guru yang mengajar

\footnotetext{
${ }^{11}$ Nana Sudjana, Penilaian Hasil Proses Belajar Mengajar, (Bandung: Remaja Rosdakarya, 2005 ), h. 22.

${ }^{12}$ Thomas A. Hermawan Martanto, Pendidikan Nasional dalam Politik dan Kemasyarakatan, (Yokyakarta: Universitas Sanata Dharma, 2008), h. 198-200.

${ }^{13}$ Ibid..., 200-201.

${ }^{14}$ Tutik Rahmawati dan Daryanto, Penilaian Kinerja Profesi Guru dan Angka Kreditnya, (Yokyakarta: Gava Media, 2013), h. 101.

${ }^{15}$ Hamzah B. Uno, Teori Motivasi \& Pengukurannya, (Jakarta: Bumi Aksara,2011), 66

${ }^{16}$ Ibid..., 72 .
} 
dan membimbing mereka. Guru yang kompeten akan lebih mampu menciptakan lingkungan belajar yang efektif, menyenangkan, dan akan lebih mampu mengelola kelasnya, sehingga kegiatan belajar para siswa berada pada tingkat optimal. ${ }^{17}$

Oleh karena itu, seseorang yang berprofesi sebagai guru, khususnya guru rumpun PAI baik yang sudah tersertifikasi maupun yang belum diharapkan memiliki pengetahuan yang luas dan keterampilan. Selain itu juga harus memiliki kompetensi, motivasi kerja dan kinerja profesional. Mengajar PAI bukanlah hanya sekedar menyampaikan materi pelajaran kepada peserta didik, tetapi mendidik, membimbing, mengarahkan, melatih, menilai, dan melakukan evaluasi.

Artikel ini difokuskan pada analisis terhadap gambaran kompetensi guru, motivasi kerja guru rumpun PAI dan hasil belajar siswa; apakah terdapat pengaruh yang signifikan dari kompetensi guru rumpun PAI terhadap hasil belajar siswa; begitu pula hanlnya dengan adakah pengaruh yang signifikan antara motivasi kerja guru rumpun PAI dan hasil belajar siswa; dan apakah terdapat pengaruh yang signifikan dari kompetensi dan motivasi kerja guru rumpun PAI terhadap hasil belajar siswa Madrasah Tsanawiyah Se KKM MTsN 1 Kabupaten Serang.

Beberapa penelitian terkait telah dilakukan diantaranya Sukanti yang menemukan bahwa peningkatan kompetensi guru dapat dilakukan dengan berbagai cara, antara lain melalui kualifikasi akademik guru, pendidikan dan pelatihan, uji sertifikasi, dan memberi kesempatan perbaikan pembelajaran. Perbaikan pembelajaran ini dapat dilakukan melalui penelitian tindakan kelas. ${ }^{18}$ Siswanta dalam penelitianya menjelaskan bahwa dengan menggunakan media visual yang dilakukan dengan tiga siklus dapat meningkatkan aktivitas, motivasi, dan prestasi belajar IPS, ditunjukkan dengan meningkatnya jumlah siswa yang melampaui nilai KKM. Karena dengan melalui media visual dapat menciptakan suasana pembelajaran yang aktif, kreatif dan menyenangkan. ${ }^{19}$ Feralys Novauli dalam penelitianya menyimpulkan bahwa (1) Kompetensi Pedagogik lebih diprioritaskan kepada pengelolaan peserta didik dengan memahami potensi dan keragaman peserta didik, memahami akan landasan dan filsafat pendidikan, mampu menyusun rencana dan strategi pembelajaran, menggunakan informasi hasil penilaian dan evaluasi untuk merancang program remedial dan pengayaan; (2) Kompetensi kepribadian antara lain, guru menghargai keanekaragaman suku dan agama yang dianut oleh masing-masing peserta didik dan menjadi teladan yang jujur, tegas, bijaksana dan mampu menjaga nama baik. (3) Kompetensi sosial, guru dapat berkomunikasi secara lisan dan tulisan, mampu bergaul secara efektif dengan peserta didik, sesama pendidik, tenaga kependidikan, orang tua/wali peserta didik; dan dapat bergaul secara santun dengan masyarakat sekitar. (4) Kompetensi profesional, guru sudah menguasai substansi keilmuan yang terkait dengan bidang studi, memahami materi ajar yang ada dalam kurikulum sekolah, memahami struktur, konsep dan metode keilmuan yang menaungi atau koheren dengan materi ajar. ${ }^{20}$ Ahmad Nurabadi menyimpulkan bahwa Motivasi lebih mengarah pada hasrat untuk kerja dengan lebih baik menurut ukuran diri mausia. ${ }^{21} \mathrm{Jadi}$, secara sederhana motivasi dapat diartikan sebagai dorongan. Secara teknis istilah motivasi dalam psikologi diartikan sebagai berikut: 1) Seluruh proses gerakan termasuk situasi yang mendorong timbulnya kekuatan pada

${ }^{17}$ Oemar Hamalik, Pendidikan Guru Berdasarkan Pendekatan Kompetensi, (Bumi Aksara, Jakarta, 2002), h. 36 .

18 Sukanti, “Meningkatkan Kompetensi Guru Melalui Pelaksanaan Penelitian Tindakan Kelas”, Jurnal Pendidikan Akuntansi Indonesia, Vol. VI, No. 1, 2008: 1-11.

${ }^{19}$ Siswanta, "Peningkatan Aktivitas, Motivasi, dan Prestasi Belajar Ilmu Pengetahuan Sosial Melalui Media Visual", http://repository.upy.ac.id/858/1/ARTIKEL

${ }^{20}$ Feralys Novauli, "Kompetensi Guru Dalam Peningkatan Prestasi Belajar Pada SMP Negeri Kota Banda Aceh”, Jurnal Administrasi Pendidikan, Volume 3, No. 1, (Februari, 2015): 45-67.

${ }^{21}$ Ahmad Nurabadi, "Peningkatan Motivasi Kerja Guru Melalui Pengembangan Kepemimpinan Kepala Sekolah”, http://ap.fip.um.ac.id/wp-content/uploads/2015/04/37. 
manusia, sikap yang dipengaruhi untuk pencapaian suatu tujuan, 2) Suatu variabel yang ikut campur tangan yang digunakan untuk menimbulkan faktor-faktor tertentu di dalam organisme, yang membangkitkan, yang mengelola, mempertahankan, dan menyalurkan tingkah laku menuju satu sasaran, dan 3) Suatu kekuatan yang mendorong atau menarik yang tercermin dalam tingkah laku yang konsisten menuju tujuan tertentu.

\section{B. Display Data Temuan}

Pengolahan data tentang pengaruh kompetensi guru rumpun PAI (X1), motivasi kerja guru rumpun PAI (X2), terhadap hasil belajar siswa (Y) dalam penelitian ini menggunakan bantuan komputasi program SPSS. Hal ini ditampilkan dalam bentuk skor rata-rata/mean, median, modus, simpangan baku/standar deviasi, nilai terendah/minimum, dan nilai tertinggi/maximum. Hasil yang diperoleh adalah sebagai berikut.

Tabel 1; Rangkuman Hasil Penelitian

\begin{tabular}{lccc}
\hline \multicolumn{1}{c}{ Deskripsi } & Kompetensi Guru & Motivasi Kerja Guru & Hasil belajar Siswa \\
\hline Rata-rata & 80,87 & 79,27 & 74,17 \\
Median & 80,00 & 80,00 & 75,00 \\
Modus & 73 & 84 & 65 \\
Standar Deviasi & 9,321 & 9,261 & 12,763 \\
Minimum & 61 & 54 & 30 \\
Maksimum & 100 & 100 & 95 \\
\hline Jml. Responden & 75 & 75 & 75 \\
\hline
\end{tabular}

Berdasarkan rekapitulasi skor hasil belajar siswa $(\mathrm{X} 1)$ diperoleh skor tertinggi $=100$, skor terendah $=61$, harga rerata $=80,87$, simpangan baku $=9,321$ median $=80,00$ dan modus $=73$.

Tabel 2; Distribusi Data Kompetensi Guru Rumpun PAI (X1)

\begin{tabular}{ccccc}
\hline No & Klasifikasi & Interpretasi & Frekuensi & Prosentase (\%) \\
\hline 1 & $61-68$ & sangat rendah & 5 & 6,66 \\
2 & $69-76$ & Rendah & 21 & 28 \\
3 & $77-84$ & Cukup & 26 & 34,66 \\
4 & $85-92$ & Tinggi & 15 & 20 \\
5 & $93-100$ & sangat tinggi & 8 & 10,66 \\
\hline
\end{tabular}

Berdasarkan distribusi frekuensi tersebut, jawaban responden terhadap kompetensi guru rumpun PAI dapat diklasifikasikan menjadi lima berdasarkan kelas atau kategori: sangat rendah, rendah, cukup, tinggi dan sangat tinggi. Dari 75 guru sebagai responden, diketahui bahwa faktor kompetensi guru yang mempunyai frekuensi tinggi pada posisi cukup. Karena nilai rata-rata jawaban responden berada pada interval $77-84$ yang menunjukkan bahwa 
faktor kompetensi guru rumpun PAI Madrasah Tsanawiyah se KKM MTs Negeri 1 Kabupaten Serang sudah cukup dengan pencapaian nilai prosentase sebesar 34,66 \%.

Berdasarkan rekapitulasi data penelitian tentang motivasi guru rumpun PAI se KKM MTs Negeri 1 Kabupaten Serang (X2) diperoleh skor sebagai berikut: skor tertinggi $=100$, skor terendah $=54$, harga rerata $=79,27$, simpangan baku $=9,261$, median $=8000$, dan modus $=84$.

Tabel 3; Distribusi Data Motivasi Kerja Guru Rumpun PAI (X2)

\begin{tabular}{ccccc}
\hline No & Klasifikasi & Interpretasi & Frekuensi & Prosentase (\%) \\
\hline 1 & $54-62$ & sangat rendah & 6 & $8 \%$ \\
2 & $63-71$ & Rendah & 10 & $13 \%$ \\
3 & $72-80$ & Cukup & 26 & $35 \%$ \\
4 & $81-89$ & Tinggi & 24 & $32 \%$ \\
5 & $90-100$ & sangat tinggi & 9 & $12 \%$ \\
\hline & Jumlah total & & 75 & 100
\end{tabular}

Berdasarkan distribusi frekuensi tersebut, jawaban responden terhadap variabel motivasi kerja guru rumpun PAI se KKM MTs Negeri 1 Kabupaten serang dapat diklasifikasikan menjadi lima berdasarkan kelas atau kategori: sangat rendah, rendah, cukup, tinggi dan sangat tinggi. Dari 75 orang guru sebagai responden, diketahui bahwa faktor motivasi guru rumpun PAI se KKM MTs Negeri 1 Kabupaten Sserang mempunyai frekuensi pada posisi rendah. Karena nilai rata-rata jawaban responden berada pada interval 72-80 yang menunjukkan bahwa faktor kompetensi guru rumpun PAI se KKM MTs Negeri 1 Kabupaten Serang masih rendah dengan pencapaian nilai prosentase sebesar $35,0 \%$.

Berdasarkan rekapitulasi hasil penelitian tentang hasil belajar siswa Madrasah Tsanawiyah kelas IX se KKM MTs Negeri 1 Kabupaten Serang (Y) diperoleh skor tertinggi $=95$, skor terendah $=30$, harga rerata $=74,17$, simpangan baku $=12,763$, median $=74,17$, dan modus $=$ 65.

Tabel 4; Distribusi Data Hasil Belajar Siswa (Y); Distribusi Data Motivasi Kerja Guru Rumpun PAI (X2)

\begin{tabular}{ccccc}
\hline No & Klasifikasi & Interpretasi & Frekuensi & Prosentase (\%) \\
\hline 1 & $30-42$ & sangat rendah & 1 & $1 \%$ \\
2 & $43-55$ & Rendah & 3 & $4 \%$ \\
3 & $56-74$ & Cukup & 30 & $40 \%$ \\
4 & $75-87$ & Tinggi & 27 & $36 \%$ \\
5 & $87-95$ & sangat tinggi & 14 & $19 \%$ \\
\hline & & & 75 & 100
\end{tabular}

Berdasarkan distribusi frekuensi tersebut, jawaban responden terhadap variabel hasil belajar siswa Madrasah Tsanawiyah kelas IX se KKM MTs Negeri 1 Kabupaten Serang dapat diklasifikasikan menjadi lima berdasarkan klas atau kategori: sangat rendah, rendah, cukup, 
tinggi dan sangat tinggi. Dari 75 orang siswa sebagai responden, diketahui bahwa faktor hasil belajar siswa mempunyai frekuensi pada posisi cukup. Karena nilai rata-rata jawaban responden berada pada interval 56-74 yang menunjukkan bahwa faktor Motivasi Kerja Guru rumpun PAI sudah cukup dengan pencapaian nilai prosentase sebesar 40,00\%.

\section{B.1 Hasil Uji Statistik Kompetensi Guru Rumpun PAI terhadap Hasil Belajar Siswa}

Hasil Uji statistic antara kompetensi guru rumpun PAI dan hasil belajar siswa dapat dilihat pada table berikut:

Tabel 5; Pedoman Interpretasi Koefisien Korelasi

\begin{tabular}{cc}
\hline Interkorelasi & Tingkat Hubungan \\
\hline $0,80-1,00$ & Sangat Kuat \\
$0,60-0,79$ & Kuat \\
$0,40-0,59$ & Cukup Kuat \\
$0,20-0,39$ & Cukup \\
$0,00-0,19$ & Lemah \\
\hline
\end{tabular}

Tingkat korelasinya dapat diketahui melaui table berikut:

Tabel 6; Korelasi Kompetensi Guru Rumpun PAI dengan Hasil Belajar Siswa

\begin{tabular}{cccc}
\hline & & Kompetensi & Hasil Belajar \\
& & Guru & Siswa \\
\hline Kompetensi Guru & Pearson Correlation & 1 & $.231^{*}$ \\
& Sig. (2-tailed) & & .046 \\
& $\mathrm{~N}$ & 75 & 75 \\
Hasil Belajar Siswa & Pearson Correlation & $.231^{*}$ & 1 \\
& Sig. (2-tailed) & .046 & \\
\cline { 2 - 4 } & $\mathrm{N}$ & 75 & 75
\end{tabular}

Berdasarkan hasil uji statistik tentang Pengaruh Kompetensi Guru Rumpun PAI terhadap Hasil Belajar siswa diperoleh nilai $r$ hitung dari variabel kompetensi guru rumpun PAI (X1) sebesar 0,231 sedang $\mathrm{r}$ tabel 0,227 ( $\mathrm{r}$ hitung $>$ dari $\mathrm{r}$ tabel) dengan Probability significant $0,000(<0,05)$, sehingga dapat diinterpretasikan memiliki hubungan yang signifikan dengan kriteria korelasi cukup yaitu sebesar 0,231.

Tabel 7; Model Summary Kompetensi guru Rumpun PAI dengan Hasil Belajar Siswa

\begin{tabular}{ccccc}
\hline Model & $\mathrm{R}$ & R Square & $\begin{array}{c}\text { Adjusted R } \\
\text { Square }\end{array}$ & $\begin{array}{c}\text { Std. Error of the } \\
\text { Estimate }\end{array}$ \\
\hline 1 & $.231^{\mathrm{a}}$ & .053 & .040 & 12.504 \\
\hline
\end{tabular}

Hasil uji koefisien determinasi bahwa variabel Kompetensi Guru Rumpun PAI ( $\left.\mathrm{X}_{1}\right)$ memiliki angka $R$ Square (derajat keeratan antara pengaruh kompetensi guru rumpun PAI terhadap hasil belajar siswa) diperoleh sebesar 0,053. Artinya bahwa hasil belajar siswa dapat 
dijelaskan oleh variabel kompetensi guru rumpun PAI sebesar 5,3\% sedangkan sisanya 94,7\% hasil belajar siswa dipengaruhi oleh variabel-variabel lain.

Tabel 8; Hasil Uji Anova Kompetensi Guru Rumpun PAI terhadap Hasil

Belajar Siswa

\begin{tabular}{cccccc}
\hline & & & & & \\
& Model & Sum of Squares & Df & Mean Square & F \\
\hline \multirow{2}{*}{1} & Regression & 641.483 & 1 & 641.483 & \\
& Residual & 11413.264 & 73 & 156.346 & \\
\cline { 2 - 6 } & Total & 12054.747 & 74 & & \\
\cline { 2 - 6 } & & & & &
\end{tabular}

Dari Tabel. 4.19 Anova $^{a}$ di atas, dijelaskan bahwa $\mathrm{F}=4.103$ dengan tingkat probabilitas Sig. 0,000 oleh karena itu probabilitas $0,000(<0,05)$ maka model regresi bisa dipakai untuk memprediksi komptensi guru rumpun PAI

Tabel 9

Hasil Uji Koefisien Kompetensi Guru Rumpun PAI terhadap Hasil Belajar Siswa

\begin{tabular}{|c|c|c|c|c|c|c|}
\hline & \multirow[b]{2}{*}{ Model } & Unstandar & Coefficients & $\begin{array}{l}\text { Standardized } \\
\text { Coefficients }\end{array}$ & \multirow[b]{2}{*}{$\mathrm{T}$} & \multirow[b]{2}{*}{ Sig. } \\
\hline & & $\mathrm{B}$ & Std. Error & Beta & & \\
\hline \multirow[t]{2}{*}{1} & (Constant) & 48.629 & 12.693 & & 3.831 & .000 \\
\hline & Kompetensi Guru & .316 & .156 & .231 & 2.026 & .046 \\
\hline
\end{tabular}

Selanjutnya dengan uji $t$ diperoleh $t$ hitung sebesar 2,026 sedang t tabel sebesar 1,992 dengan probability significancy $0,000(<0,05)$. Dalam hal ini berarti $t$ hitung $>\mathrm{t}$ tabel, maka $\mathrm{H}_{\mathrm{o}}$ ditolak dan $\mathrm{H}_{1}$ diterima. Sehingga dapat dikatakan bahwa Kompetensi berpengaruh positif terhadap Hasil Belajar siswa.

Uji hipotesis dilakukan dengan membandingkan tingkat signifikansi dengan nilai $<(5 \%)$. Data tersebut menunjukkan bahwa tingkat signifikansi untuk variabel independen (kompetensi guru rumpun PAI) adalah $0,000<0,05$, sehingga dapat disimpulkan bahwa hipotesis pertama mengenai adanya hubungan kompetensi guru rumpun PAI dengan hasil belajar siswa kelas IX Madrasah Tsanawiyah se KKM MTs Negeri 1 Kabupaten Serang dapat dibuktikan.

\section{B.2 Hasil Uji Statistik Motivasi Kerja Guru Rumpun PAI terhadap Hasil Belajar Siswa}

Hasil Uji statistic hubungan motivasi kerja guru rumpun PAI dan hasil belajar siswa dapat dilihat pada table berikut:

\begin{tabular}{|c|c|c|c|}
\hline & & $\begin{array}{c}\text { Motivasi Kerja } \\
\text { Guru }\end{array}$ & $\begin{array}{c}\text { Hasil Belajar } \\
\text { Siswa }\end{array}$ \\
\hline \multirow[t]{3}{*}{ Motivasi Kerja Guru } & Pearson Correlation & 1 & .394 \\
\hline & Sig. (2-tailed) & & .421 \\
\hline & $\mathrm{N}$ & 75 & 75 \\
\hline \multirow[t]{3}{*}{ Hasil Belajar Siswa } & Pearson Correlation & .394 & 1 \\
\hline & Sig. (2-tailed) & .421 & \\
\hline & $\mathrm{N}$ & 75 & 75 \\
\hline
\end{tabular}


Berdasarkan uji statistik bahwa pengaruh motivasi kerja guru rumpun PAI terhadap hasil belajar siswa diperoleh $\mathrm{r}$ hitung dari variabel motivasi kerja guru rumpun PAI $\left(\mathrm{X}_{2}\right)$ sebesar 0,394 sedang $\mathrm{r}$ tabel 0,227 ( $\mathrm{r}$ hitung $>$ dari $\mathrm{r}$ tabel) dengan probability signifikancy $0,000(<$ $0,05)$, sehingga dapat diinterpretasikan memiliki hubungan yang signifikan dengan kriteria korelasi kuat yaitu sebesar 0,394.

Tabel 11; Model Summary Pengaruh Motivasi kerja terhadap Hasil Belajar Siswa

\begin{tabular}{ccccc}
\hline Model & $\mathrm{R}$ & R Square & $\begin{array}{c}\text { Adjusted R } \\
\text { Square }\end{array}$ & Std. Error of the Estimate \\
\hline 1 & $.394^{\mathrm{a}}$ & .115 & .615 & 12.793 \\
\hline
\end{tabular}

Hasil uji koefisien determinasi bahwa variabel motivasi kerja guru rumpun PAI ( $\left.\mathrm{X}_{2}\right)$ memiliki angka $R$ Square (derajat keeratan pengaruh motivasi kerja guru rumpun PAI terhadap hasil belajar siswa) diperoleh sebesar 0,155. Artinya bahwa hasil belajar siswa dapat dijelaskan oleh variabel motivasi kerja guru rumpun PAI sebesar $15,5 \%$, sedangkan sisanya $84,5 \%$ hasil belajar siswa dipengaruhi oleh variabel-variabel lainnya.

Tabel 12; Hasil Uji Anova pengaruh Motivasi Kerja Guru Rumpun PAI terhadap Hasil Belajar siswa

\begin{tabular}{ccccccc}
\hline & Model & Sum of Squares & Df & Mean Square & F & Sig. \\
\hline \multirow{2}{*}{1} & Regression & 107.380 & 1 & 107.380 & .656 & $.421^{\mathrm{a}}$ \\
& Residual & 11947.367 & 73 & 163.663 & & \\
\cline { 2 - 7 } & Total & 12054.747 & 74 & & & \\
\hline
\end{tabular}

Dari Tabel. 4.23 Anova $^{\mathrm{a}}$ di atas, dijelaskan bahwa $\mathrm{F}=0,656$ dengan tingkat probabilitas Sig. 0,000 oleh karena itu probabilitas $0,000(<0,05)$ maka model regresi bisa dipakai untuk memprediksi Motivasi Kerja Guru Rumpun PAI.

Tabel 13; Hasil uji Koefisien Pengaruh Motivasi Kerja Guru Rumpun PAI terhadap Hasil Belajar Siswa

\begin{tabular}{|c|c|c|c|c|c|c|}
\hline & \multirow[b]{2}{*}{ Model } & \multicolumn{2}{|c|}{ Unstandardized Coefficients } & \multirow{2}{*}{$\begin{array}{c}\begin{array}{c}\text { Standardized } \\
\text { Coefficients }\end{array} \\
\text { Beta }\end{array}$} & \multirow[b]{2}{*}{$\mathrm{T}$} & \multirow[b]{2}{*}{ Sig. } \\
\hline & & B & Std. Error & & & \\
\hline \multirow[t]{2}{*}{1} & (Constant) & 63.863 & 12.814 & & 4.984 & .000 \\
\hline & MotivasiKerjaGuru & .130 & .161 & .094 & 2.810 & .421 \\
\hline
\end{tabular}

Selanjutnya dengan uji t diperoleh $\mathrm{t}$ hitung sebesar 2,810 sedang t tabel sebesar 1,992 dengan probability significancy $0,000(<0,05)$. Dalam hal ini berarti $\mathrm{t}$ hitung $>\mathrm{t}$ tabel, maka $\mathrm{H}_{\mathrm{o}}$ ditolak dan $\mathrm{H}_{1}$ diterima. Sehingga dapat dikatakan bahwa motivasi kerja guru rumpun PAI berpengaruh positif terhadap hasil belajar siswa.

Uji hipotesis dilakukan dengan membandingkan tingkat signifikansi dengan nilai $<(5 \%)$. Data tersebut menunjukkan bahwa tingkat signifikansi untuk variabel independen (motivasi kerja guru rumpun PAI adalah $0,000<0,05$, sehingga dapat disimpulkan bahwa hipotesis kedua mengenai pengaruh motivasi kerja guru rumpun PAI terhadap hasil belajar siswa kelas IX Madrasah Tsanawiyah se KKM MTs Negeri 1 Kabupaten Serang dapat dibuktikan. 


\section{B.3 Hasil Uji Statistik Pengaruh Kompetensi Guru dan Motivasi Kerja Guru Rumpun PAI Terhadap Hasil Belajar Siswa}

Hasil uji statistik antara pengaruh kompetensi guru dan motivasi kerja guru rumpun PAIN terhadap hasil belajar siswa dapat dilihat pada tabel berikut:

Tabel 14; Pengaruh Kompetensi dan Motivasi Kerja Guru Rumpun PAI terhadap Hasil Belajar Siswa

\begin{tabular}{llccc}
\hline & & $\begin{array}{c}\text { Kompetensi } \\
\text { Guru }\end{array}$ & $\begin{array}{c}\text { Motivasi Kerja } \\
\text { Guru }\end{array}$ & $\begin{array}{c}\text { Hasil Belajar } \\
\text { Siswa }\end{array}$ \\
\cline { 3 - 5 } Kompetensi Guru & Pearson Correlation & 1 & $.562^{* *}$ & $.231^{*}$ \\
& Sig. (2-tailed) & & .000 & .046 \\
& $\mathrm{~N}$ & 75 & 75 & 75 \\
Motivasi Kerja Guru & Pearson Correlation & $.562^{* *}$ & 1 & .394 \\
& Sig. (2-tailed) & .000 & & .421 \\
& $\mathrm{~N}$ & 75 & 75 & 75 \\
Hasil Belajar Siswa & Pearson Correlation & $.231^{*}$ & .394 & 1 \\
& Sig. (2-tailed) & .046 & .421 & \\
& $\mathrm{~N}$ & 75 & 75 & 75 \\
\hline
\end{tabular}

Hasil uji statistik mengenai pengaruh kompetensi dan motivasi kerja guru rumpun PAI terhadap hasil belajar siswa diperoleh nilai $r$ hitung dari variabel kompetensi guru rumpun PAI (X1) dan motivasi kerja guru rumpun PAI $\left(\mathrm{X}_{2}\right)$ secara bersama-sama adalah sebesar 0,394 sedang $\mathrm{r}$ tabel 0,227 ( $\mathrm{r}$ hitung $>$ dari $\mathrm{r}$ tabel) dengan probability signifikancy kompetensi guru rumpun PAI 0,000 $(<0,05)$, dan probability signifikancy motivasi kerja guru rumpun PAI $0,000(<0,05)$, oleh karena $\mathrm{r}$ hitung $>$ dari $\mathrm{r}$ tabel, maka dapat diinterpretasikan memiliki pengaruh yang signifikan.

Tabel 15; Model summary Pengaruh Kompetensi dan Motivasi Kerja Guru Rumpun PAI terhadap Hasil Belajar Siswa

\begin{tabular}{ccccc}
\hline Model & $\mathrm{R}$ & R Square & $\begin{array}{c}\text { Adjusted R } \\
\text { Square }\end{array}$ & Std. Error of the Estimate \\
\hline 1 & $.235^{\text {a }}$ & .055 & .029 & 12.578 \\
\hline
\end{tabular}

Berdasarkan uji koefisien determinasi bahwa pengaruh antara dua variabel independen $\left(\mathrm{X}_{1}\right.$ dan $\mathrm{X}_{2}$ ) dengan variabel dependen $(\mathrm{Y})$ yakni digunakan $R$ Square (derajat keeratan hubungan). Dalam hal ini adalah sebesar 0,055. Artinya bahwa hasil belajar siswa dapat dijelaskan oleh variabel kompetensi guru dan motivasi kerja guru rumpun PAI secara bersama-sama sebesar $5,5 \%$, sedangkan sisanya yaitu sebesar 94,5\% hasil belajar siswa dipengaruhi oleh variabelvariabel lainnya yang tidak diteliti dalam penelitian ini.

Tabel 16; Hasil Uji Anova Pengaruh Kompetensi dan Motivasi Kerja Guru Rumpun PAI terhadap Hasil Belajar Siswa

\begin{tabular}{ccccccc}
\hline & Model & Sum of Squares & Df & Mean Square & F & Sig. \\
\hline \multirow{1}{*}{1} & Regression & 663.436 & 2 & 331.718 & 4.097 & $.130^{\mathrm{a}}$ \\
& Residual & 11391.311 & 72 & 158.213 & & \\
\cline { 2 - 7 } & Total & 12054.747 & 74 & & & \\
\hline
\end{tabular}

Selanjutnya koefisien korelasi tersebut digeneralisasikan melalui uji F. Dalam hal ini nilai F hitung dari variabel kompetensi dan motivasi kerja guru rumpun PAI secara bersama-sama 
sebesar 4,097 sedang $\mathrm{F}$ tabel sebesar 3,120 dengan demikian $\mathrm{F}$ hitung $>$ dari $\mathrm{F}$ tabel, maka koefisien korelasi ganda yang diuji adalah signifikan.

Tabel 17

Hasil Uji koefisien Pengaruh Kompetensi dan Motivasi Kerja Guru Rumpun PAI terhadap Hasil Belajar Siswa

\begin{tabular}{|c|c|c|c|c|c|c|}
\hline & \multirow[b]{2}{*}{ Model } & \multicolumn{2}{|c|}{ Unstandardized Coefficients } & \multirow{2}{*}{$\begin{array}{c}\begin{array}{c}\text { Standardized } \\
\text { Coefficients }\end{array} \\
\text { Beta }\end{array}$} & \multirow[b]{2}{*}{$\mathrm{t}$} & \multirow[b]{2}{*}{ Sig. } \\
\hline & & B & Std. Error & & & \\
\hline \multirow[t]{3}{*}{1} & (Constant) & 51.054 & 14.333 & & 3.562 & .001 \\
\hline & Kompetensi Guru & .356 & .190 & 260 & 1.875 & .065 \\
\hline & Motivasi Kerja Guru & .071 & .191 & .052 & .373 & .711 \\
\hline
\end{tabular}

Uji hipotesis dilakukan dengan membandingkan tingkat signifikansi dengan nilai $<(5 \%)$. Berdasarkan tersebut bahwa tingkat signifikansi untuk variabel independen adalah $<0,05$ sehingga dapat disimpulkan bahwa hipotesis ketiga adanya hubungan variabel independen kompetensi dan motivasi kerja guru rumpun PAI secara bersama-sama dengan variabel dependen hasil belajar siswa kelas IX Madrasah Tsanawiyah se KKM MTs Negeri 1 kabupaten Serang dapat dibuktikan.

Model persamaan regresi yang dihasilkan koefisien regresi yang ada pada tabel 4.28, selanjutnya ditulis dalam model persamaan regresi adalah $\mathrm{Y}^{1}=51,054+0,356 \mathrm{X}_{1}+0,071 \mathrm{X}_{2}$. Model persamaan regresi tersebut mengandung arti bahwa nilai konstanta positif sebesar 51,054, hal ini menunjukkan jika nilai Kompetensi guru rumpun PAI $\left(\mathrm{X}_{1}\right)$ dan motivasi kerja guru rumpun PAI $\left(\mathrm{X}_{2}\right)$ bernilai nol, maka perluasan hasil belajar siswa $(\mathrm{Y})$ bernilai positif sebesar angka tersebut. Selanjutnya kompetensi guru rumpun PAI $\left(\mathrm{X}_{1}\right)$ mempunyai pengaruh yang positif terhadap hasil belajar siswa. Hal ini ditunjukan oleh koefisien regresi sebesar 0,356. Artinya setiap kenaikan kompetensi guru rumpun PAI $1 \%$ maka hasil belajar siswa akan mengalami kenaikan sebesar 35,6 \%. Untuk motivasi kerja guru rumpun PAI $\left(\mathrm{X}_{2}\right)$ mempunyai pengaruh yang positif terhadap hasil belajar siswa. Hal ini ditunjukan oleh koefisien regresi $\left(\mathrm{X}_{2}\right)$ sebesar 0,071. Artinya setiap kenaikan motivasi kerja guru rumpun PAI sebesar 1\% maka hasil belajar siswa akan mengalami kenaikan sebesar 7,1\%.

\section{B. 4 Kompetensi dan Motivasi Guru, serta Hasil Belajar Siswa}

Gambaran mengenai pengaruh kompetensi guru rumpun PAI se KKM MTs Negeri 1 Kabupaten Serang, peneliti melakukan observasi dan penyebaran kuisioner kepada 75 guru rumpun PAI dari 59 Madrasah Tsanawiyah yang tergabung di KKM MTs Negeri 1 Kabupaten Serang yang dijadikan responden. Adapun alat ukur dari Kompetensi guru rumpun PAI meliputi: kompetensi paedagogik, kompetensi profesional, kompetensi sosial dan kompetensi kepribadian. Berdasarkan hasil jawaban responden dan analisis korelasi dengan menggunakan SPSS mengenai variabel kompetensi guru rumpun PAI didapat rata-rata jawaban 80,87 dengan kategori cukup. Hal tersebut menunjukkan bahwa guru sebagai sebagai responden, diketahui bahwa kompetensi guru mempunyai frekuensi pada posisi cukup. Karena nilai ratarata jawaban responden berada pada interval 77-84 yang menunjukkan bahwa hasil belajar siswa sudah cukup dengan pencapaian nilai prosentase sebesar 34,66\%. Memperhatikan hasil analisis statistik tersebut menunjukkan bahwa responden memberikan nilai positif terhadap kompetensi guru rumpun PAI di Madrasah Tsanawiyah se KKM MTs Negeri 1 Kabupaten Serang. Meskipun secara keseluruhan kompetensi guru rumpun PAI telah cukup, namun masih terdapat hal-hal yang perlu ditingkatkan. Salah salah satunya adalah peningkatan kompetensi 
sehingga guru rumpun PAI dapat menyelesaikan permasalahannya dalam melaksanakan tugas kesehariannya.

Berdasarkan hasil jawaban responden dan analisis dengan menggunakan SPSS mengenai variabel motivasi kerja guru rumpun PAI se KKM MTs Negeri 1 Kabupaten Serang didapatkan skor rata-rata sebesar 79,27 dengan kategori cukup. Hal tersebut menunjukkan bahwa guru sebagai responden, diketahui bahwa motivasi kerja guru mempunyai frekuensi pada posisi cukup. Karena nilai rata-rata jawaban responden berada pada interval 72-80 yang menunjukkan bahwa motivasi kerja guru sudah cukup dengan pencapaian nilai prosentase sebesar 35,00\% memberikan jawaban positif terhadap motivasi kerja guru rumpun PAI se KKM MTs Negeri 1 Kabupaten Serang. Dari hasil gambaran dan analisis di atas, menunjukkan bahwa pada umumnya motivasi kerja guru rumpun PAI dilihat dari indikatornya yang meliputi motivasi internal dan motivasi eksternal yang secara keseluruhan telah sesuai dengan harapan.

Sedangkan gambaran mengenai hasil belajar siswa Madrasah Tsanawiyah se KKM MTs negeri 1 Kabupaten Serang, peneliti melakukan penyebaran soal test kepada siswa kelas IX sebanyak 75 orang yang dijadikan responden. Adapun alat ukur dari hasil belajar siswa meliputi : Al Qur'an Hadits, Fiqih, SKI, Aqidah Akhlak. Berdasarkan hasil jawaban responden dan analisis korelasi dengan menggunakan SPSS mengenai variabel hasil belajar siswa Madrasah Tsanawiyah se KKM MTs Negeri 1 Kabupaten Serang didapatkan jawaban dengan skor rata-rata 74,17 dengan kategori cukup . Hal tersebut menunjukkan bahwa siswa sebagai responden, diketahui bahwa hasil belajar mempunyai frekuensi pada posisi cukup. Karena nilai rata-rata jawaban responden berada pada interval 56-74 yang menunjukkan bahwa hasil belajar siswa sudah cukup dengan pencapaian nilai prosentase sebesar $40,00 \%$.

Dari hasil analisis data dan pendapat responden mengenai Pengaruh Kompetensi dan motivasi kerja guru rumpun PAI terhadap hasil belajar siswa, secara simultan terdapat pengaruh positif dan signifikan dengan total hubungan sebesar 5,5\%. Dengan demikian menunjukkan bahwa kedua variabel berpengaruh terhadap hasil belajar siswa. Meskipun demikian masih terdapat faktor-faktor lain yang berpengaruh terhadap hasil belajar siswa tetapi tidak diteliti sebesar $94,5 \%$ seperti motivasi dan minat belajar siswa, pengembangan kurikulum, sarana dan prasarana, kepemimpinan kepala sekolah, bimbingan orang tua dan lain sebagainya. Oleh karena itu, secara umum dapat disimpulkan bahwa pengaruh kompetensi dan motivasi kerja guru rumpun PAI terhadap hasil belajar siswa Madrasah Tsanawiyah se KKM MTs Negeri 1 Kabupaten Serang hanya sedikit saja yakni 5,5 persen.

\section{Penutup}

Terdapat pengaruh yang signifikan dari kompetensi guru rumpun PAI terhadap hasil belajar siswa Kelas IX Madrasah Tsanawiyah se KKM MTs Negeri 1 kabupaten Serang pada mata pelajaran rumpun PAI dengan hasil uji $t=2,026$, sedangkan $t$ tabel sebesar 1,992, nilai probabilitas $0,00<0,05$ sehingga hipotesis $\mathrm{H} 0$ ditolak yang berarti kompetensi guru berpengaruh positif terhadap hasil belajar siswa pada mata pelajaran rumpun PAI, yakni Alqur'an Hadits, Fiqih, SKI dan Aqidah ahlak. Ada pengaruh yang signifikan dari motivasi kerja guru rumpun PAI terhadap hasil belajar siswa Kelas IX Madrasah Tsanawiyah se KKM MTs negeri 1 kabupaten Serang dengan hasil uji $\mathrm{t}=2,810$ sedangkan $\mathrm{t}$ tabel sebesar 1,992, nilai probabilitas $0,000<0,05$ sehingga hipotesis $\mathrm{H} 0$ ditolak yang berarti, dan motivasi kerja berkontribusi positif terhadap hasil belajar siswa pada mata pelajaran rumpun PAI, yakni Alqur'an Hadits, Fiqih, SKI dan Aqidah akhlak. Ditemukan pula pengaruh yang signifikan dari kompetensi guru dan motivasi kerja guru rumpun PAI terhadap hasil belajar siswa kelas IX Madrasah tsanawiyah se KKM MTs Negeri 1 kabupaten serang secara simultan hal ini ditunjukkan dengan perolehan hasil uji $\mathrm{F}$ sebesar 4, 097 sedang $\mathrm{F}$ tabel sebesar 3,12, dengan nilai probabilitas sebesar $0,000<0,05$, maka hipotesis keempat dalam penelitian inipun 
terbukti bahwa terdapat pengaruh yang signifikan dari seluruh variabel bebas terhadap variabel terikat secara serentak atau bersama-sama.

\section{Daftar Pustaka}

B. Uno, Hamzah. Teori Motivasi \& Pengukurannya. Jakarta: Bumiaksara, 2011. dan Nina Lamatenggo. Teori Kinerja dan Pengukuran. Jakarta: Bumi Aksara, 2012.

Hamalik, Oemar. Pendidikan Guru Berdasarkan Pendekatan Kompetensi. Jakarta: Bumi Aksara, 2002

Hermawan, Thomas, Pendidikan Nasional dalam Politik dan Kemasyarakatan. Yogyakarta: Universitas Sanata Darma, 2008.

Kementerian Agama RI, Alqur'an dan Terjemahnya. Jakarta: PT Sinergi Pustaka Indonesia, 2012.

Kunandar, Guru Profesional: Implementasi Kurikulum Tingkat Satuan Pendidikan (KTSP) dan Persiapan Menghadapi Sertifikasi Guru. Jakarta: Raja Grafindo, 2008.

Mulyasa. Standar Kompetensi Guru dan Sertifikasi Guru. Bandung: Remaja Rosdakarya, 2008.

---------. Uji Kompetensi dan Penilaian Kinerja Guru. Bandung: Remaja Rosdakarya, 2013.

Novauli, Feralys. "Kompetensi Guru Dalam Peningkatan Prestasi Belajar Pada SMP Negeri Kota Banda Aceh”. Jurnal Administrasi Pendidikan. Volume 3, No. 1, (Februari, 2015): 45-67

Nurabadi, Ahmad. "Peningkatan Motivasi Kerja Guru Melalui Pengembangan Kepemimpinan Kepala Sekolah”. $\quad$ http://ap.fip.um.ac.id/wp-content/uploads/2015/04/37_AhmadNurabadi-AP.pdfProgram Pascasarjana IAIN SMHB, Pedoman Penulisan Tesis, Serang 2015.

Rahmawati, Tutik dan Daryanto. Penilaian Kinerja Profesi Guru dan Angka Kreditnya. Yogyakarta: Gaya Media, 2013.

Sardiman. Interaksi dan Motivasi Mengajar. Jakarta: Rajagrafindo Persada, 2004.

Siswanta. "Peningkatan Aktivitas, Motivasi, dan Prestasi Belajar Ilmu Pengetahuan Sosial Melalui Media Visual", http://repository.upy.ac.id/858/1/ARTIKEL\%20UPAYA\%20\%20PENINGKATAN\%20 AKTIVITAS $\% 20 \% 20-\% 20 \% 20$ Siswanta\%20repotari.pdf.

Sudjana, Nana. Penilaian Hasil Proses Belajar Mengajar. Bandung: Remaja Rosdakarya, 2005.

Sukanti, “Meningkatkan Kompetensi Guru Melalui Pelaksanaan Penelitian Tindakan Kelas". Jurnal Pendidikan Akuntansi Indonesia. Vol. VI No. 1, 2018: 1-11.

Undang-Undang Republik Indonesia Nomor 14 tahun 2005 Tentang Guru dan Dosen. Jakarta: Novindo Pustaka Mandiri, 2006.

Undang-Undang Nomor 20 tahun 2003 tentang Sistem Pendidikan Nasional. 